\title{
The Translatability of Military Terms by MA Students in Translation at Yarmouk University in Jordan
}

\author{
Mohammad Alshehab \\ Jadara University, Jordan
}

Received: 01-06-2014

doi:10.7575/aiac.ijclts.v.2n.3p.56
Accepted: 29-06- 2014

Published: 01-07- 2014

URL: http://dx.doi.org/10.7575/aiac.ijclts.v.2n.3p.56

\begin{abstract}
This paper aimed at examining the level of students' ability in translating military expressions from English into Arabic at Yarmouk University (YU) in Jordan. For achieving its goals, the researcher selected a random sample of (20) Master (MA) students, who are studying English-Arabic translation at the 'Translation Department. They enrolled in the first semester (2011-2012). The researcher used a validated and reliable text; it was used previously to examine military personnel at the Military Academy in Jordan. This text includes (25) English military expressions to be translated into Arabic. Quantitatively, percentages and mean scores were computed to know the level of students' ability in translating military expressions and phrases. Qualitatively, the analysis was set up to investigate their Arabic translation. The study recommended a number of recommendations to overcome the low level of students' translation in translating military expressions and phrases. Furthermore, further researches in military translation were suggested.
\end{abstract}

Keywords: Military expressions, Master students' translatability, Yarmouk University.

\section{Introduction}

Military translation has played a crucial role since the early days of Islamic growth. Muslim armies benefited greatly from the expertise of the translators they encountered in the nations they conquered. The armies were moving through areas with different languages and cultures. Despite the fact that Arabs have had a very rich military history, they have had to depend on foreign armies to develop and modernize their armies. As a result, they have to keep up with the massive inflow of new military technology and terminology.

Military translation is a scientific type of translation. Bell (2006) says that military terminology refers to the terms that are used by military organizations and military personnel. They belong to a distinct group, as it is apparent by their usage in military policies and communications. Some claimed that military terms serve to depoliticize, dehumanize, or otherwise provide a means for an abstract discussion about operations from an actual description thereof. Similar to "legal terminology" and related to "political terminology", military terms are known for their oblique tendency to incorporate technical language. In many cases, they reflect a need to be precise. They can also reflect a perceived need for operational security, giving away no more information than needed.

Military translation is similar to other types of translation. Differences emerge due to the types of message forms that display features. These types may distinguish them from other types of translation. They do not necessarily mean that special approaches should be adopted in military translation. The types only reflect the nature of the task, which military translators face.

According to Nida (1969), the translator's duty is to come up with the closest natural equivalence. Hence, a military translator is required to be truly bilingual, bicultural, open-minded, and knowledgeable in the field of military sciences. With these qualities, military translators will be able to bridge the gap between SL and TL. Newmark best describes their position when he stated; "Translation is a craft consisting in the attempt to replace a written message and /or statement in one language by the same message and /or statement in another language (Newmark, 1981 p.7).

Jalabneh (1991) meets Alshehab (2009) in saying that armies in the developing countries vitally depend on the exchange of information with other Western countries. The dependence represents in building up their forces through the aid of more advanced armies abroad, and to keep up with the ever-advancing military technology.

For the importance of military translation in the Arab world, Jalabneh (1991) points out that the Arab Military Academies have issued pamphlets and compiled dictionaries for military terms. Alshehab (2013) says that military experts investigated and purified the military terms that were issued by the Arab organizations within their military field. Consequently, these new military terms were added to the unified Arab dictionaries. He explains the significance of paying more attention to terminological expressions in the military field.

Alshehab (2009) argues that it is crucial to find new terms because modern Arab armies have been modeled, as said before, in their structure, branches, weaponry, and ranking according to the modern Western and Eastern Armies. Consequently, they need new coinages, translations, and revival of older terms to meet the fresh requirements of a modern army with a Western design. These efforts have been carried out by Arab Language Academies. Among these are the Academy of the Arab Language in Damascus (1919), the Academy of the Arab Language in Cairo 
(1934), the Scientific Academy of Iraq (1948), the Academy of the Arab Language in Amman (1980), and the Academy of Bait Al-Hikma in Tunis (1983).

Al-Abed Al-Haq $(1986,1989,1996)$ adds that Arab universities, and some Arab lexicographers and translators of scientific texts have made efforts to supply translation equivalents in Arabicized forms. Nevertheless, translators from different Arab countries use different Arabic technical equivalents of the same term. Moreover, the planned terminology involves term choice, term policy formulation, term policy codification, term policy elaboration, term policy implementation, and term policy evaluation.

Alshehab (2013) says, military terms were treated as similar to other technical terms when they were planned. Terms that are planned are altered in some way (purified, reformed, standardized, revived, modernized) to enhance communication within and between nations. He continues that studies of military translation had concentrated on compiling military dictionaries and pamphlets related to different branches in the Jordanian Armed Forces.

Few military studies were carried out at the national level. Alshehab (2013) published a paper aimed at investigating the impact of Language Planning (LP), Arabicization planning, and terminology planning on military terminology and translation. It provided guidelines for the applications of language planning on military terminology and translation at the national level in Jordan. His paper dealt with the five types of LP, e.g., purification, revival, reformation, standardization, and modernization. A list of 70 military terms and expressions were chosen from the dictionary of 'Military Terminology'. The analysis of military terminology was used within LP types, Arabicization, and Terminology Planning. Each type was investigated, and the suitable English military examples and their Arabic translation were posed.

Alshehab (2009) wrote a study aimed at investigating the difficulties in translating military terms from English into Arabic and vice versa. He used two military English texts and one Arabic text. The sample was the military personnel who studied English courses at the Jordanian Academy. The results revealed a fair level for the personnel in translating military expressions from English into Arabic. In addition, it showed a number of issues resulted from their English and Arabic translation.

Alshehab (1999) conducted a study aimed at comparing between the translations of military terms from English into Arabic. It was a comparative study between two Arab armies, the Iraqi and the Jordanian armies. He also focused on the causes of the dissimilarity between the Arabic military equivalents, not only between the two Arab armies, but also among all the Arab armies. The researcher used a list of 94 military terms as a sample selected from some of the military dictionaries and pamphlets used in Jordan and in Iraq to be investigated. The results showed a great disparity between the Arabic equivalents in spite of the fact that some of the terms had been Arabicized in the same manner.

Jalabneh (1991) studied the major problems of military translation. He used 165 members from the Jordanian Armed Forces (JAF) of different positions, responsibilities, and ranks. A Questionnaire and an interview were used. The methods focused on; the importance of translation for the JAF, the types of message forms handled by military translators, the quality of military translation, and finally, some suggested guidelines and approaches aimed at enhancing the efficiency of military translators. The study revealed that translators could use more than one model in translation if not all of them. The majority of the audiences of military translators preferred simple styles and structures that focused on the main ideas of the subject as opposed to literal translation.

Al-Smady (1998) investigated two sets of 50 military terms. The first was accomplished and Arabicized by the Academy of the Arabic Language in Jordan, and the other was proposed by the users in the Jordanian Armed Forces. The results indicated that the items proposed by the users were more acceptable than the items Arabicized by the Academy of the Arabic Language in Jordan.

\subsection{Research Problem}

As previously mentioned, it was seen, the number of translation studies in the military field is rare and insufficient. Most of them were conducted by using military personnel as samples within the military field. No studies have been done at the academic level dealing with university students. Consequently, the researcher takes into his consideration to carry out a series of military translation researches, using various samples in different universities in Jordan. In this study, the researcher selected 20 Master (MA) students, who are studying English Arabic translation at YU as a public university in Jordan. By this, regarding the researcher's knowledge, the researcher could contribute a little bit to bridge the gap that is still ignored in the military translation.

\subsection{Research Question}

The study aims at examining the level of students' ability in translating military expressions from English into Arabic at Yarmouk University (YU) in Jordan. In order to achieve its objective, the following two questions are posed:

1. What is the level of ability of MA translation students in translating military terms and expressions from English into Arabic at $Y U$ in Jordan?

2. How could MA translation students translate military terms and expressions from English into Arabic at YU in Jordan? 
Although many military books and dictionaries are available in the military field, this study is, on the best of the researcher's knowledge, the first that has been done in the academic field. It will help to explain how military terms in specific areas are translated or rendered by persons having no background or an idea about the Arabic equivalents of these terms. Moreover, it gives us an idea about the difficulty of obtaining close equivalents for military terminology. As no previous study has attempted to answer the questions posed. I believe that a study of this type will shed more light on the interaction between English and Arabic in the military field. It is hoped that this research will contribute in enhancing the field of research in military translation.

\subsection{Limitations of the Study}

This study is limited to a number of MA translation students, who enrolled in the first academic semester (20112012). Although the number of the sample may not be large enough, it would be adequate to validate the findings. Moreover, the English text is limited to 25 military terms and expressions to be translated into Arabic.

\section{Methodology}

The methodology employed in this study gives a description of the sample, theoretical framework, and methods such as; data collection represented by the study's model, the research design and procedure, and the analytical methods.

\subsection{The Sample of the Study}

The population consists of all MA translation students enrolled in the first semester (2011-2012). They have studied translation at Yarmouk University (YU) in Jordan. They were taught a number of courses such as; legal translation, administration and finance translation, and literary translation. A sample of 20 translation students was chosen to be examined, and to know the level of their ability in translating military lexical terms and expressions from English into Arabic through a text model.

\subsection{Theoretical Framework}

The four models (grammatical, cultural, interpretive, and text-typological) are advocated by a number of Arabic scientists and military experts, e.g., (Jalabneh, 1991; Shunnaq, 1994; Chau, 1997). All of models, regarding the researcher's view are suitable to be utilized as suitable approaches in analyzing military terms and messages. The researcher viewed that to carry out translation task; military translators can deal with applying all models as each model has its own gains in military translation. The researcher adopted here the cultural model.

\subsection{Data collection: Study's Model}

An English military text was chosen to examine the students' level of ability in translating military lexical terms and expressions into Arabic. The text had been used previously to examine the military personnel in the Jordanian Academy. The text had been validated and its reliability was verified by Alshehab (2009). Two military professionals were chosen as a 'committee' to translate the text into Arabic resulting two versions. For more validity regarding the current study, the versions were exposed to "a panel of judges" -professionals- from the English Language Department at YU and Irbid National University in Jordan. They were asked to write in detail their comments and suggestions. Their comments and suggestions were taken into consideration, followed by setting up a final version as Professional Translation with excellent level.

\subsection{Research Design and Procedure}

The English text was distributed to the selected students (sample) with special absolute papers. The expressions that were included in the text were given serial numbers; they were arranged in the English text. The researcher followed Alshehab's (2009) criteria for evaluating the Arabic translation for English military expressions. See table 1.

Table 1. The Procedure of Translating or Evaluating Military Expressions from

English into Arabic

\begin{tabular}{cccc}
\hline Professional Translation & \multicolumn{3}{c}{ Student translation } \\
\hline Excellent & Good & Fair & Poor \\
\hline 4 & 3 & 2 & 0 \\
\hline
\end{tabular}

From the table above, it can be clearly observed that when the student's translation is similar to that of the professional's (denotative), the expression scores (4). If the student scores (4) for all (25) expressions $(4 \times 25=100)$ then his level will be excellent. When synonyms are used by the student (connotative), this level is evaluated as "good" and the expression scores (3). If the rendering of the expression is only partly right, it will be graded as (2) and its level is "fair". Finally, the expression may be given a score of zero, which is equivalent of "poor" if its rendering is completely wrong. For example, if the student scores full marks for (20) items (4), good marks (3) for (2) items, fair marks (2) for 2 items, and failed in (1) items; $(20 \times 4+2 \times 3+2 \times 2+1 \times 0=91)$. He is considered to be at the excellent level. See the following criteria: 
Table 2. Evaluation Criteria

\begin{tabular}{cl}
\hline Levels \% & Evaluation \\
\hline Above 85 & Excellent \\
$70-<85$ & Good \\
$50-<70$ & Fair \\
\hline $00-<50$ & Poor \\
\hline
\end{tabular}

The dependent variable is the students' ability in military translation from English into Arabic. It is hypothesized under the influence of independent variable that are believed to cause, influence or lead to variations in the dependent variable (Odeh\& Malkawi , 1991).

\subsection{Analytical Method}

In the present study, the researcher has adopted both quantitative and qualitative methods for analyzing data. The quantitative method is verified by calculating percentages, means, and ranks, followed by discussing and analyzing students' responses as a qualitative analysis.

\section{Results and Discussions}

For answering Q1: What is the level of ability of MA translation students in translating military terms from English into Arabic at $\mathrm{YU}$ in Jordan?

Table 3 shows the percentages of students' scores. The total mean score of the students' translation for these terms and expressions is $(46 \%)$. It is a poor level in translating military terms.

Regarding the above criteria, one student obtains an excellent level with 87 percent; three students obtain a good level with the percentages of 81,77 , and 74 respectively. Six students achieve the fair level. On the other hand, ten students failed in achieving the fair level and failed in their translating military expressions and phrases.

The overall poor level with $46 \%$ is not good for postgraduate students at YU as a Government University in Jordan. It seems that no attention is paid for the military subject. It seems that no military courses are posed to be studied. Whereas these expressions are well known in Arabic military translation as tactical expressions, but they are not known at the academic level. Few students, however, have tried to utilize the suitable equivalents. Conversely, more of them failed to give the Arabic military equivalents for these expressions. It is expressed that their proficiency in English language is not high enough to overcome this deficiency.

Table 3. Students' level of Military Translation at YU in Jordan

\begin{tabular}{ccc}
\hline No & Grade $\%$ & Rank \\
\hline 1 & 51 & 8 \\
2 & 50 & 9 \\
3 & 66 & 5 \\
4 & 27 & 15 \\
5 & 77 & 3 \\
6 & 34 & 13 \\
7 & 20 & 17 \\
8 & 18 & 18 \\
9 & 39 & 12 \\
10 & 26 & 16 \\
11 & 14 & 19 \\
12 & 46 & 11 \\
13 & 32 & 14 \\
14 & 60 & 7 \\
15 & 50 & 9 \\
16 & 81 & 2 \\
17 & 74 & 4 \\
18 & 62 & 6 \\
19 & 87 & 1 \\
20 & 0 & 20 \\
Mean to All & 46 & - \\
\hline & &
\end{tabular}


For answering Q2: How could MA translation students translate military terms and expressions from English into Arabic at $Y U$ in Jordan?

The mean scores, percentages, and ranks were computed for each item as shown in Table 4. The results of Arabic translation for the English military expressions. The highest percent is for the English expression "Armored" that means in Arabic دروع (doroa'). It has achieved a good level of 2.96 mean score and 74 percent. A fair level is for the English expressions "Missiles" صاروخ ( التجسس (aqmar attajasuss). They have achieved above 60 \%, their mean scores 2.56, 2.48, 2.40 respectively, with the percentages $(64,62$, and 60).

Table 4. Percentages of Military Expressions

\begin{tabular}{|c|c|c|c|c|}
\hline No & Expression & Mean & $\%$ & Rank \\
\hline 1 & Direct combat & 2.48 & 62 & 3 \\
\hline 2 & Close support & 2.00 & 50 & 6 \\
\hline 3 & Combat Support Arms & 2.00 & 50 & 6 \\
\hline 4 & Infantry & 1.60 & 40 & 11 \\
\hline 5 & Armored & 2.96 & 74 & 1 \\
\hline 6 & Mechanized & 0.96 & 24 & 23 \\
\hline 7 & Airborne & 1.36 & 34 & 14 \\
\hline 8 & Air assault & 1.28 & 32 & 16 \\
\hline 9 & Rifle & 1.76 & 44 & 9 \\
\hline 10 & Grenades & 1.60 & 40 & 11 \\
\hline 11 & Tow Heavy Antitank Missile & 1.24 & 31 & 18 \\
\hline 12 & Dragon Medium Antitank Missile & 1.16 & 29 & 19 \\
\hline 13 & Field artillery weapons & 1.60 & 40 & 11 \\
\hline 14 & Air defense weapons & 1.92 & 48 & 8 \\
\hline 15 & Shoulder-held Redeye & 1.16 & 29 & 19 \\
\hline 16 & Army aviation & 1.04 & 26 & 21 \\
\hline 17 & Aircraft, fixed wing and helicopters & 1.36 & 34 & 14 \\
\hline 18 & Rotary wing & 0.72 & 18 & 24 \\
\hline 19 & Armored reconnaissance vehicle & 1.00 & 25 & 22 \\
\hline 20 & Salient orbits & 0.48 & 12 & 25 \\
\hline 21 & Spy satellites & 2.40 & 60 & 4 \\
\hline 22 & Remotely controlled sensors & 2.08 & 52 & 5 \\
\hline 23 & Interlocking electronic circuits & 1.28 & 32 & 16 \\
\hline 24 & Laser-beams & 1.68 & 42 & 10 \\
\hline \multirow[t]{2}{*}{25} & Missiles & 2.56 & 64 & 2 \\
\hline & Mean for all items & 1.59 & 39.68 & \\
\hline
\end{tabular}

Similarly, the fair level $(52,50,50)$ percent, is for the English expressions "Remotely controlled sensors" التحكم عن بعد "Cort (attaHakum a'n bua'd fi alHasssaat), "Close support" اسناد قريب في الحساسات (isnaad qareeb) and "Combat Support Arms” أسلحة اسناد القتال (asliHat isnad alqital).

The English expression “Air Defense Weapons" "أسلحة الدفاع الجوي" (aslihat ad difaa' aljawi) has achieved the eighth rank with 48 percent. On the other side, the English expression "Rifle" بندقية(Bondeqyeh) has achieved the ninth level in its Arabic translation. The English expression: (Laser-Beams) أشعة ليزر (ashia'at layzer) has been translated by most of the students as (lazer). It has been scored the tenth rank with 42 percent. This expression should achieve more than this result as it is being dealt with at the public level by all.

The English lexical terms and expressions "Infantry” "مشاة" (mushaatt), “Grenades” قنابل يدوية (qanabil yadawiyah), and "Field artillery weapons" have achieved the eleventh rank with 40\%. The equivalents of "Field Artillery Weapons" stray from the correct translation thereby its rendering as مجال المدفعية) (majal almadfa'iyah) that means “Artillery Range" and أسلحة المدفعية (aslihat almadfa'iyah) that means in English "Artillery Weapons". The correct translation is: “'أسلحة مدفعية الميدانة (asliHat madfa 'iyaht al maydan) "Weapons Artillery Field”. 
The English expression: "Dragon Medium Antitank Missile" صاروخ دراغون المضاد للابابات (Saruukh dragon almudhad liddababaat), "Shoulder-held Redeye Missile" صاروخ ريداي المحمول على الكتف (Saruukh raid i almaHmuul a'la alkatif) have got the mean score of 1.16 with 29 percent. Some renderings for "Dragon Medium Antitank Missile" stray from the correct translation thereby its rendering as: "صواريخ ضد الدبابات "(Sawariikh dhid addababat) " (asliHah dhid addababatt). Some students translated "Shoulder-held Redeye" as صاروخ ضدريد (Saaruukh raid i) "RedEye Missile". They deleted the expression "Shoulder-held" that gives the correct meaning for the military personnel.

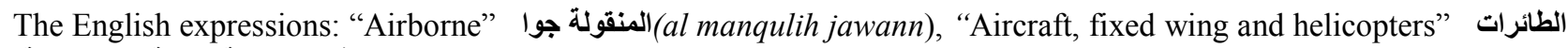
الهجوم " (alTae raatt that alajniHah alThaabitah w ala'amuudiyah), and "Air Assault سواء ذات الاجنحة الثابتة و العامودية الجوي (alhujum al jawii), have obtained the rank 14, 14, and 16 with the percent of (34, 34, and 32). A more correct translation into Arabic is الججوم الجويthat means "Air force Attack".

The English expressions: "Army aviation", "Armored reconnaissance vehicle", "Mechanized", "Rotary wing", and "Salient orbits" have achieved the lowest levels of translation. Their Arabic translation is مركبات الاستطلاع ,طيران "الجيش" " اللدارات العالية ,الأجنحة الدوارة ,الية ,المدرعة. Their mean scores are 1.04, 1.0, 0.96, 0.72, and 0.48 for the English expression "Salient orbits" 26, 25, 24, and 12 percent.

Some problems appeared when translating a number of military terms. Some of the students could not distinguish between "two" اثثين and "Tow", the brand name of a weapon used in the Western Armies or by their companies. This expression is not given any equivalence by the Arabic Language Academy. It is transliterated as a borrowed term. Similarly, some of the students have mistranslated the English expression "Grenades". They failed to give a correct Arabic equivalent for this expression because of their lack of knowledge in distinguishing between "Grenades"(qanaabil yadawiyah) قنابل يدوية, and the general term "bombs" Some students translated it as "جنابل ajyaal that means "generations". It is a social term that is not related to any kind of weapon.

The results have revealed the existence of a number of Arabicized terms that have been utilized by students; four of them were borrowed from the English language without alterations in Arabic, e.g., "Redeye ", "Tow" and "Dragun". The results showed the lack of good knowledge in translating most of the military terms that have caused changes in the meaning. Thus, the results of this study are different from any result of the related studies. The low level of translation students is clearly distinguished, as they obtained below $50 \%$ and failed in their mean score.

The study meets all of the previous studies in dealing with military translations. Many of them such as (Al-Shehab, 2013, 1999; Al-Smady, 1998; Jalabneh, 1991) focused on translation of military terms used by the Jordanian army. The present study meets Alshehab's (2009) in translating military expressions from English into Arabic, on the one side. On the other side, the current study used a sample of MA translation students at YU in Jordan, while Alshehab's (2009) used military personnel who studied military courses at the Jordanian Military Academy. It is assumed that they are familiar in using English military expressions at their field. By comparing the results, this study shows the lowest level in finding the appropriate Arabic renderings for the English military terms.

\section{Recommendations and Suggestions}

The low result of students' translatability may be ascribed to a lack of good control mechanism in dealing with such subject. Thus, in the light of the poor level in military translatability, the study recommends and suggests for:

a. Issuing translation course at the academic level at schools in Jordan, this could contribute in enhancing students' translation, particularly military.

b. Paying more attention by English Departments to military translation for military purposes from English into Arabic and vice versa.

c. Initiating translation groups, and conducting national conferences and workshops at the Jordanian universities discussing views regarding various issues in translation from English into Arabic, including military translation.

d. Carrying out empirical researches in analyzing military topics and articles collectively and individually at various education levels.

e. Carrying out researches that could test and examine English students' ability in military translation.

\section{Conclusion}

This paper has examined the level of MA translation students at Yarmouk University in Jordan. The most noticeable result to emerge from this study is a low and a poor level in students' translation of military terms and expressions. This result demands studying a course of military translation, and future trial to assess its impact in this field. In addition, further researches in military translation would be of a great help in improving students' ability in military translation.

\section{References}

Al-Abed Al-Haq, F. (1986). Arabicization in Jordan. International Journal of Islamic and Arabic Studies. 3, (2) pp. 6. 312 .

Al-Abed Al-Haq, F. (1989). Implication of Language Planning into Arabicization in Jordan. International Journal of Islamic and Arabic Studies 6, (2).

Al-Abed Al-Haq, F. (1996). Towards a Theoretical Framework for The Study of Planning Arabicization. A Paper presented to the 13th conference on linguistics, literature translation: Yarmouk University. Irbid, Jordan. 
Alshehab, M. (2013). The impact of language planning, terminology planning, and Arabicization on military terminology planning and translation. Journal of Research on Humanities and Social Science, Vol. 3, No.16, pp.62-72.

Alshehab, M. (2009). Issues in translating military terms and texts between English and Arabic.Unpublished Ph.D Thesis: University of Science and Technology, Malaysia.

Alshehab, M. (1999). Arabicization of Military Terms: A Comparative study. Unpublished Master Thesis. Yarmouk University, Irbid, Jordan.

Al-Smady, M. (1998). Language Planning and Arabicization of Military Terms. Unpublished Master Thesis in linguistics. Yarmouk University. Irbid, Jordan.

Bell, R. (2006). Ballistic Missile Threats: NATO. Russia strategic challenge in Krasnaya Zvezda. NATO on -line Library, 2 (28).

Chau, S. (1984). Aspects of Translation Pedagogy: the grammatical, cultural, and interpretive teaching models. University of Edinburgh.

Farghal, M., Shunnaq, A. (1999). Translation With Reference to English and Arabic. A practical guide. Irbid: Dar alhilal for translation.

Jalabneh, M. (1991). A Study in the Issues of Military Translation. Amman, Dar-Al Khawajah.

Nahir, M. (1977). The Five Aspects of Language Planning- a classification. Language problems and language planning1, pp. 107-122.

Newmark, P. (1981). Approaches to Translation, Oxford: Pergamon Press. London.

Newmark, P. (1995). Paragraph on Translation. Clevedon: Multilingual Matters Ltd.

Nida, E. (1964). Towards a Science of Translating: with special reference to principles and procedures involved in Bible translation, Leiden: Brill.

Nida, E., Taber, C. (1982). The Theory and Practice of Translation. (Leiden: E. J Brill, 1964).

Odeh. A., Malkawi, K. (1991). Research Method in Education and Psychology (2nd Ed), Dar Al-Amel, Amman, Jordan.

Sager, J. C. (1990). A Practical course in terminology processing. Amsterdam Philadelphia: John Benjamin.

Sano, M., Mackell, J., Ponton, M., Ferreira, P., Wilson, J., Pawluczyk, S., Schafer, K., Schittini, M., Grundman, M., Ferris, S \& Thal, L. (1997). The Spanish instrument protocol: Design and implementation of a study to evaluate treatment efficacy instruments for Spanish-speaking patients with Alzheimer's disease. Alzheimer Disease and Associated Disorders, 11 (Suppl. 2),S57 S64

Shunnaq, A. (1993). Lexical Incongruence in Arabic-English Translation due to Emotiveness in Arabic.In Turjumān (2.2), pp. 37-63. 